\title{
数字及び拡散光弁別課題下での反復呈示刺激 に対する視覚誘発電位の増大
}

\section{富山大学 室橋春光}

\section{An enhancement of human visual evoked potentials to stimulus repetition during number and diffuse light discrimination tasks}

\author{
MUROHASHI, Harumitsu
}

Department of Special Education, Faculty of Education, Toyama University 3190 Gofuku, Toyama 930, Japan.

\begin{abstract}
Amplitude characteristics of visual evoked potentials to number (sharp contour) and blurred spot (diffuse contour) stimuli were examined in this experiment. Five male and two female college students were exposed to a series of trials. Each trial consisted of the presentation of seven successive stimuli — a warning stimulus followed by a first triplet of three identical stimuli (stimulus positions 1-3) and a second triplet of another three identical stimuli (positions 4-6). For the numerical stimuli which possessed sharp contours, subjects were required to identify the stimulus pattern by name. For the blurred spot stimuli with diffuse contours, only eye fixation was required of the subjects. Analysis of occipital P260 amplitude revealed significant enhancement at stimulus positions 2 and 3 for the numerical stimuli but not for the blurred spot stimuli. These findings were discussed in terms of the representation process during visual perception.
\end{abstract}

Key words : visual evoked potentials, occipital P260 enhancement, contour clearness, pattern processing.

\section{視覚誘発電位(VEP)の後頭部成分のひとつであ} る潜時 $170 \mathrm{~ms}$ の陰性波 (N170)の振幅は, 視覚的選 択あるいは注意に対応して変動する ( Harter \& Guido, 1980)。潜時270msの陽性波(P270)の振幅 も注意に対応して変動することが指摘されている
が (Donchin \& Cohen, 1967)，この成分に対応す る心理学的機能はまだ十分解明されたとはいえな い。

Kitajima, Murohashi, \& Kanoh (1980, 1981$)$ は，数字(文字)とチェッカー模様の刺激を継時的 に反復呈示する方法によってP270の分析を試み た。その結果, 後頭領 P 270の振幅值が数字刺激 及びチェッカー模椂の刺激の反復呈示により増大 
することを見出した ( Kitajima，Murohashi， \& Kanoh, 1983)。同一刺激の反復呈示は, 誘発電位 の振幅值を減少させるといわれている(e.g., Callaway, 1973)。しかし Kitajima et al. (1980,

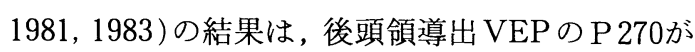
パタン刺激弁別課題の処理に伴うある種の心理学 的機能を反映することを示唆している。

刺激を反復呈示すると知覚学習が進行し, その 刺激に対する処理のありかたが変化する(Gibson \& Gibson, 1955)。視覚情報処理理論によれば, 刺 激情報は特徵検出系により処理された後に知覚表 象として合成され記憶される (e.g., Lindsay \& Norman, 1977)。このような基礎的段階の情報処 理においては, 知覚学習の影響を受けにくい。他 方, 高次の処理は, 知覚学習の影響を受けやすい (Rumelhart \& Siple, 1974)。Kitajima et al. (1980，1981，1983）の実験では被験者は大学生で あり, 数字や文字のような刺激については過剩学 習をしている。他方, チェッカー模様について は，必ずしも過剩学習をしていない。したがって 数字や文字が刺激として反復呈示されるといちは やく知覚学習が進行し, チェッカー模様よりも初 期に安定した知覚的表象化が行われるといえる。 すなわち，Kitajima et al. (1980，1981，1983）に 颃ける後頭領導出 $\mathrm{P} 270$ 成分は刺激の反復呈示に 伴ら振幅值変化からみて, 安定した知覚的表象化 に関連している可能性がある。

Harter \& Guido(1980)は, grating あるいは拡散 光を呈示し，視覚的注意を向けたときのVEPを 検討した。その結果, 潜時 $150-250 \mathrm{~ms}$ の後頭領導 出の陰性変動成分は, 輪郭の有無により変化した。 Kitajima et al. (1980, 1981, 1983)における後頭領 導出 P 270成分は, その潜時からみると輪郭の処 理になんらかのかたちで関わりをもつ可能性があ る。輪郭の処理はより高次の視覚情報処理段階に 属し, 知覚的表象の形成により直接的に関与する と考えられる。よって本論文では, 明瞭な輪郭の 有無が後頭領導出 P 270 成分に及ぼす影響を検討
することを目的とする。

\section{方 法}

被験者視力（矯正視力を含む）の正常な大 学生 7 名 (男子 5 名, 女子 2 名)。

刺激 3 種類の刺激を用いた。そのうち2 種 類は課題刺激, 1 種類は警告刺激である。課題刺 激のひとつは，2から9までの数字である（数字 刺激)。この刺激の作成には, $12 \times 12$ ユニットの チェッカーボード基盤（1ユニットは $5 \mathrm{~mm} \times 5 \mathrm{~mm}$ で, 全ユニットに対角線がいれてある）を用い， 斜線を含めて各数字刺激を作成した（Fig. 1 参 照)。他の課題刺激は輪郭の不明瞭なほぼ円形の 刺激（拡散円光刺激）で, 数字刺激の基盤と同じ 大きさの灰色の色紙を長焦点レンズ（ $f=135 \mathrm{~mm} ）$ の焦点をずらして接写することにより作成した。 警告刺激は， $12 \times 12$ ユニットのランダムパタンと した (Fig. 1参照)。これら 3 種類の刺激はいずれ も，そのネガをスライド刺激として利用した。い ずれのスライド刺激も図柄は白, 背景は黒で, 図 柄部分の明るさは約 $3 \mathrm{~cd} / \mathrm{m}^{2}$, チェッカーボー ド基盤の視角度は約 3 。であった。刺激持続時間 は300msで，スライドプロジェクターに高速 シャッターを装着することによりコントロールし た。

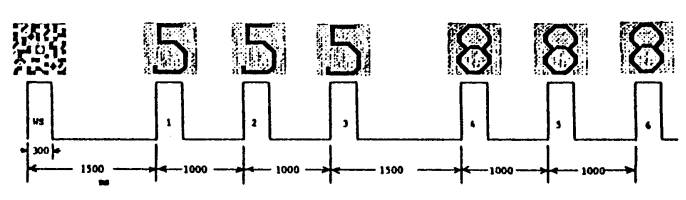

Fig. 1 A schematic presentation of the stimulus sequence. One sec. after the stimulus in position 6, the subjects were required to report the number in each triplet. Blurred spot stimuli were presented in the same way as that for the number stimuli except no verbal report was required. 
手続き数字試行と拡散円光試行を実施した。 いずれも 7 つの刺激から成り，最初に警告刺激， 次に最初の課題刺激 3 つ（同一課題刺激の反復呈 示，これらを第一課題刺激列と呼ぶ），さらに次 の課題刺激 $3 つ($ 同一課題刺激の反復呈示, 第二 課題刺激列) で構成した。ひとつの試行内では, 第一，第二いずれの課題刺激列も同じ種類の刺激 を呈示した。な扮数字試行では，第二課題刺激列 に現われる数字は, 第一課題刺激列に現われる数 字とは異る場合があった（異／同比は0.5で，同 刺激試行と異刺激試行はランダムに配列)。第一 及び第二課題刺激列内の刺激を区別するために， 呈示順序に従って第一課題刺激列の一番目の刺激 を刺激位置 1 の刺激と呼び，以下刺激位置 $2 ， 3$ の刺激と呼ぶ。また第二課題刺激列の一番目の刺 激を刺激位置 4 の刺激と呼び，以下刺激位置 5 , 6 の刺激と呼ぶ。警告刺激と刺激位置 1 の刺激と の刺激間間隔 (on-on) は $1500 \mathrm{~ms}$ ，第一及び第二課 題刺激列内の刺激間間隔はいずれも $1000 \mathrm{~ms}$ ，また 刺激位置 3 の刺激と刺激位置 4 の刺激との刺激間 間隔は $1500 \mathrm{~ms}$ であった。

26試行を 1 ブロックとして 6 ブロックの刺激呈 示を行った。試行間間隔は不規則で平均 $20 \mathrm{~s}$, ブ ロック間には休憩（約 $2 \mathrm{~min}$ ）を入れた。ブロック 内では数字試行と拡散円光試行の数は等しく, そ れらの出現順序はランダムになるように配列した。

被験者は電気的遮蔽を施した暗室内に置かれた 歯科用安楽椅子にすわり，その約 $1 \mathrm{~m}$ 前方にある プラスチック製半透明スクリーンに映写されるス ライド刺激を両眼視条件で観察した。暗順応後, 被験者に対してスクリーン中央に常に呈示される 赤色凝視点を見るよらに教示した。数字試行に対 する課題は，第一及び第二課題刺激列に現われる ふたつの数字を読み取り, 最終刺激呈示の約“1 s 後に読みとった数字を口頭で報告することであっ た。拡散円光試行では，第一・第二いずれの課題 刺激列の刺激も全て同一の拡散円光であった。こ の試行に対する課題は，注視する必要はないが呈
示刺激から視線をとらさないことであり，各試行 後の報告は求めなかった。

脳波記録電極は血型銀一塩化銀電極で, 国 際10-20法による前頭領左右 $\left(F_{3}, F_{4}\right)$, 中心領中央 $(\mathrm{Cz})$, 頭頂領左右 $\left(\mathrm{P}_{3}, \mathrm{P}_{4}\right)$, 及び後頭領左右 $\left(\mathrm{O}_{1}, \mathrm{O}_{2}\right)$ に配置した。また基準電極は両耳垂結合 とした。他に, 右眼上側及び右側に, 眼球運動を 監視するための電極を配置した。脳波計（周波数 帯域 $0.1 \mathrm{~Hz}-3 \mathrm{kHz}$, 時定数 $1.5 \mathrm{~s}$ ）の出力は F M データレコーダ（周波数帯域 d.c. $-1.25 \mathrm{kHz}$ )によ り記録した後, これを再生してミニコンピュータ により加算処理した。脳波及び眼球運動記録は記 録紙に残し，眼球運動や体動の生じた試行は加算

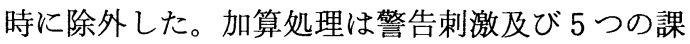
題刺激(刺激位置 $1-5$ ) のそれぞれを含む $8 \mathrm{~s}$ 間 について行った。な打刺激位置 6 の刺激について は, この刺激呈示に続いて行われる口頭報告の準 備のアーチファクトが混入しやすいため, 加算処 理をしなかった。加算回数は40-60回で, 分析精 度は7.8ms／pointであった。

データ分析 視覚誘発電位上の成分のピーク

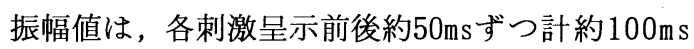
間の平均電圧值をベースラインとして測定した。 視覚誘発電位の成分振幅值の刺激間変動を検討す るために, 刺激位置 2 及び 3 の刺激に対する各成 分振幅值から, 刺激位置 1 の刺激に対する同一成 分振幅值をそれぞれ差し引いた。そしてその差の 大きい方の值を, 刺激位置間変動の指標として用 いた。振幅值変化の統計的有効性の検定には, 主 に, 繰り返しを伴う二元分散分析（刺激の種類 対 電極位置)を用いた。

\section{結果}

被験者 7 名の警告刺激及び課題刺激（刺激位置 1-5）に対する視覚誘発電位を総計した波形を Fig. 2 に示す。これらの波形は, 中心領中央 $(\mathrm{Cz})$, 後頭領左右 $\left(\mathrm{O}_{1}, \mathrm{O}_{2}\right)$ から導出・記録したも のである。な怙右端には眼球運動記録(E.M.)を示 
した。Fig. 2をみると，中心領中央導出のVEP波 形には, 潜時約 $140 \mathrm{~ms}$ の陰性成分 (N140), 潜時約 200ms及び300-500msの陽性成分（P 200，P 350） が認められた。そして第一課題刺激列に対する VEP波形では, 各成分とも, 数字刺激と拡散円光 刺激に対する振幅值の差は小さい。他方, 後頭領 導出 VEP 波形では，数字試行に対してのみ潜時 約 $180 \mathrm{~ms}$ の陰性成分（N180）及び潜時約 $260 \mathrm{~ms}$ の 陽性成分（P 260）が明瞭に認められた。

前頭領, 中心領及び頭頂領から導出した VEP の陰性成分（N140：前頭領及び中心領，あるい はN180：頭頂領）とふたつの陽性成分（P200： 前頭領及び中心領，あるいはP 260 ：頭頂領，な らびに P 350 ：前頭領，中心領及び頭頂領）の各 振幅值の被験者間平均值を Fig. 3 に示す。また Fig. 4 には, 後頭領導出 VEP の陰性成分 (N180) 及び陽性成分（P 260）の被験者間平均値を示す。

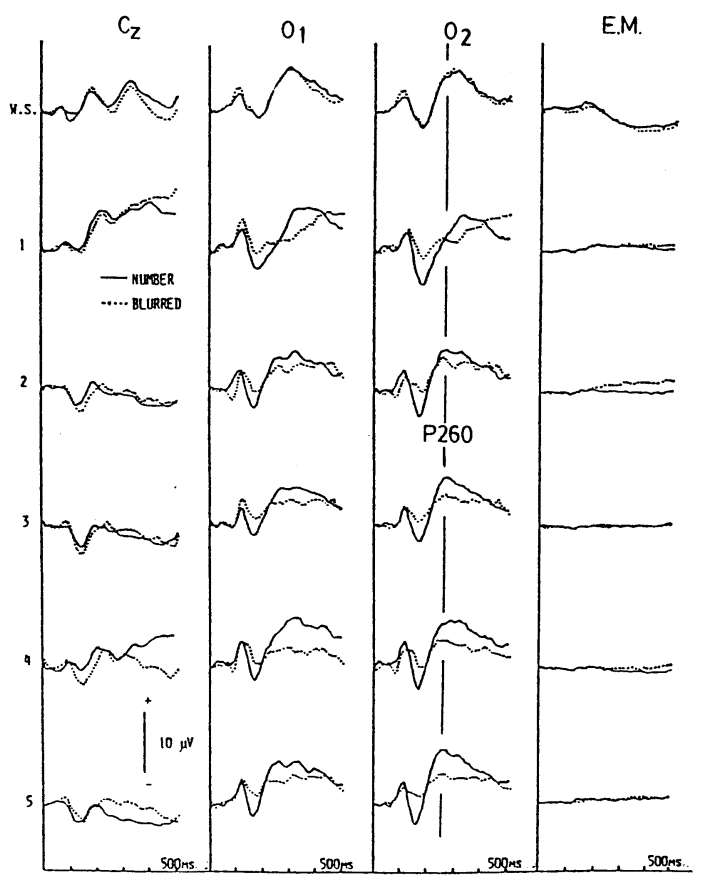

Fig. 2 VEP and EOG waveforms averaged over seven subjects for the number and blurred spot stimuli. Stimulus positions WS and $1-5$ are seen along the ordinate.
なお各グラフにおける刺激位置 1 の左側にある黒 丸及び四角は，警告刺激に対する各成分の平均振 幅值を示す。

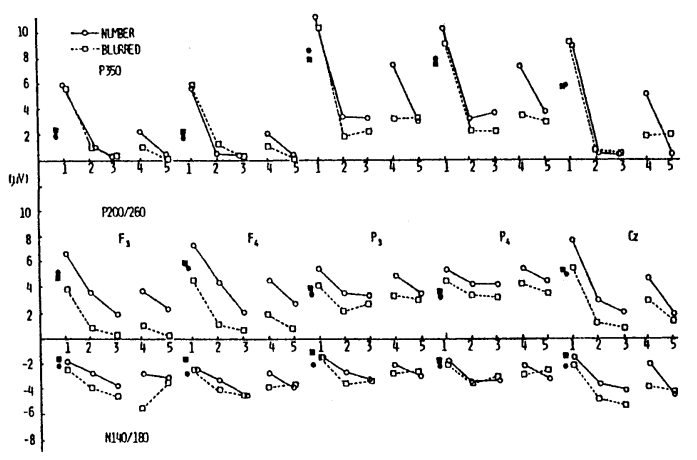

Fig. 3 The centrofrontal and parietal VEP amplitude values measured from the baseline for the number and blurred spot stimuli. Each trace was obtained through averaging the VEP amplitude values over seven subjects. The numbers on the abscissae of each panel indicate the intratrial stimulus positions. Amplitude values for the warning stimuli are shown near position 1 .

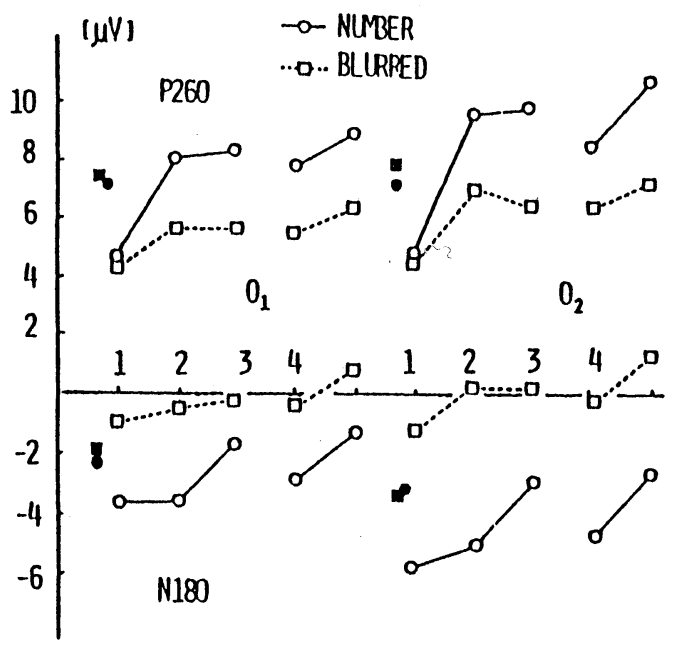

Fig. 4 The occipital VEP amplitude values measured from the baseline. All details are the same as those in Fig. 2, except that P350 amplitude valules are not shown. 
後頭領導出N180成分

刺激位置 1-3に抢ける数字刺激に対するN 180 の刺激位置間の振幅值変化（刺激位置 1 の刺激に 対するN 180振幅值と, 刺激位置 2 あるいは 3 の 刺激に対する同成分振幅值の差）之，抁散円光刺 激に対する同成分の刺激位置間の振幅值変化を比 ベたとき，有意な差は生じなかった。3つの刺激 位置 $(1,2,3)$ におけるN 180振幅值の各值をデー タとして用いたときには, 数字刺激と搪散円光刺 激に対する N 180振幅值の間に有意差が生じた $\left(\mathrm{O}_{1}\right.$ について, $\mathrm{F}(1,42)=10.49, \mathrm{p}<0.005$; $\mathrm{O}_{2}$ について, $\left.\mathrm{F}(1,42)=22.37, \mathrm{p}<0.005\right)$ 。

後頭領導出 P 260成分

刺激位置 1 の数字刺激に対する P 260振幅值は, 同位置の拡散円光刺激に対する P 260振幅値とほ ぼ等しかった。しかし数字刺激に対する P 260の 刺激位置間 (1-3)振幅值変化と, 拡散円光刺激に 対する同成分の振幅值変化を比べたときには, 有 意な差が生じた $(\mathrm{F}(1,28)=4.21, \mathrm{p}<0.05)$ 。

Fig. 4にみられるよらに，数字刺激に対する P 260 の振幅值变化の方が拡散円光刺激に対する変化よ りも明らかに大きい。また刺激位置 $1,2,3$ 各刺 激に対する P 260振幅値をデータとしたとき，数 字試行においてのみ各刺激位置の刺激に対する同 成分の振幅值間に有意差が生じた $\left(\mathrm{O}_{1}\right.$ について， $\mathrm{F}(2,24)=6.14, \mathrm{p}<0.025 ; \mathrm{O}_{2}$ について, $\mathrm{F}$ $(2,24)=3.88, \mathrm{p}<0.05)$ 。

前頭領ならびに中心領及び頭頂領導出 VEP 成分

5 つの電極位置 $\left(\mathrm{F}_{3}, \mathrm{~F}_{4}, \mathrm{C} z, \mathrm{P}_{3}, \mathrm{P}_{4}\right)$ から導出し た陰性成分（N140あるいはN 180）について，数 字刺激に対する刺激位置間(1-3)の振幅值変化と 拡散円光刺激に対する振幅値変化を比べたとき， 有意な差は生じなかった。

5 つの電極位置 $\left(\mathrm{F}_{3}, \mathrm{~F}_{4}, \mathrm{C} z, \mathrm{P}_{3}, \mathrm{P}_{4}\right)$ から導出し た陽性成分（P200あるいはP 260, 及びP 350）の 振幅值は，いずれも刺激位置 1 において最大で,
刺激位置 2 及び 3 で減少した。しかし数字刺激に 対するこれらの成分の刺激位置間 (1-3)の振幅值 変化と拡散円光刺激に対する振幅值変化を比べた ときには，有意な差は生じなかった。

\section{考察}

本実験に打ける後頭領導出の後期陽性成分 $\mathrm{P}$ 260は, 数字, 拡散円光の両刺激の反復呈示に対 して振幅值の増大を示した。このとき，拡散円光 刺激の反復呈示に対する P 260 振幅值の増大はわ ずかであり，数字刺激に対してのみ有意な振幅值 の増大を生じた。

Megela, Teyler, \& Hesse (1977) 及び Megela \& Teyler (1979) は, 視覚刺激（言語刺激及び非言 語刺激あるいは拡散光）を凝視するのみの条件で それらを反復呈示したとき，後頭領導出の陰性一 陽性成分（潜時100-200ms）の振幅值が次第に減 少することを示した。この結果は, 視覚刺激が凝 視条件のみで反復呈示されるときには，後頭領導 出の後期陽性成分の振幅值は減少することを示し ている。したがって本実験に括いて課題刺激の反 復呈示により生じた後頭領導出の後期陽性成分 $\mathrm{P}$ 260の振幅值增大は, 課題解決過程の進行に伴う 特異的な現象であると推定される。

Harter \& Guido(1980)は, 潜時150-250ms の後頭 領導出の陰性変動成分が刺激に輪郭が存在する場 合にのみ生ずることを示した。本実験では，数字 試行に㧧ける後頭領導出のN180振幅值は, 拡散 円光試行に拈ける同成分振幅值よりも有意に大き かった。この結果は輪郭処理に関連する陰性変動 が，数字刺激に対するN180振幅值に反映された ことを示しているといえよう。

一方, 数字試行に扣ける後頭領導出の P 260 の 振幅值変化は，拡散円光試行に括ける同成分の振 幅值変化よりも明らかに大きかった。このP 260 の振幅值増大については，陽性成分独自の増大を 反映するものではなく，視覚的注意の減少に伴う 陰性変動成分の減少に附随した現象であるとみる 


\section{生理心理 5 巻2号 1987}

考光もあ。すなわち，陰性変動成分が P 260に 重畳しているために，陰性変動成分の減少によっ てみかけ上の P 260振幅值が増大したとみる考兄 方である。しかし, 刺激位置 1 では刺激の弁別が 行われたと推定されるにもかかわらず, 数字刺激 に対するP 260振幅值は拡散円光刺激に対する同 成分振幅值にほぼ等しかった。したがって本実験 に拈ける後頭領導出P 260は, 輪郭処理に直接関 連するよらな陰性変動を反映したとは言いがたい。 一方, 数字試行に招ける刺激位置 1 から 2 あるい は 3 にかけてのP260の振幅值変化は, 拡散円光 試行の場合よりも有意に大きかった。この結果 は, P 260が輪郭処理に続いて生ずる安定的な知 覚表象形成のための, なんらかの最終的な処理段 階を反映することを示唆している。しかし，この 解釈については輪郭の複雑度や表象化の水準を統 制することにより，今後さらに詳細に検討する必 要がある。

\section{引用文献}

Callaway, E. 1973 Habituation of averaged evoked potentials in man. In H. V. S. Peek \& M. J. Herz (Eds.), Habituation. vol. 2, Physiological Substrates. New York : Academic Press. Pp. 153-174.

Donchin, E., \& Cohen, L. 1967 Averaged evoked potentials and intramodality selective attention. Electroenceph. Clin. Neurophysiol., 22, 537-546.

Gibson, J. J., \& Gibson, A. E. 1955 Perceptual learning : Differentiation or enrichment? Psychol. Rev., 62, 32-41.
Harter, M. R., \& Guido, W. 1980 Attention to pattern orientation : Negative cortical potentials, reaction time and the selective processes. Electroenceph. Clin. Neurophysiol., 49, 410-475.

Kitajima, S., Murohashi, H., \& Kanoh, M. 1980 Visual evoked potentials associated with the verbal and non-verbal problem-solving processes. Biol. Psychol., 10, 103-114.

Kitajima, S., Murohashi, H., \& Kanoh, M. 1981 Task redundancy and an enhancement of the late positive components in human visual evoked potentials. Biol. Psychol., 12, 223-236.

Kitajima, S., Murohashi, H., \& Kanoh, M. 1983 Stimulus repetition and an amplitude increase of the occipital late positive component in the human visual evoked potentials. Electroen ceph. Clin. Neurophysiol., 55, 567-574.

Lindsay, P. H., \& Norman, D. A. 1977 Human Information Processing : An Introduction to Psychology. New York: Academic Press.

Megela, A. L., Teyler, T. J., \& Hesse, G. W. 1977 ERP response decrement and recovery as a function of stimulus type and scalp location. Physiol. Behav., 19, 15-22.

Megela, A. L., \& Teyler, T. J. 1979 Habituation and human evoked potential. J. Comp. Physiol. Psychol., 93, 1154-1170.

Rumelhart, D. E., \& Siple, P. 1974 Process of recognizing tachistoscopically presented words. Psychol. Rev., 81, 99-118. 